術前の心肺機能では高鈴者群が対照群より有意に劣勢 な parameter はなかったが, 高齢者 AVR 群で術後 CI の有意の低下および気管内チューブ挿管時間の遷延 傾向がみられた.

これらの心肺機能の術後低下傾向は，左室破裂の発生 にみられるごとく心筋の脆弱性, AVR 後の房室伝導障 害などとと屯に手術負荷に対する高秢者の潜在的弱点と みられる. 石死化 AS の大動脈弁輪は狭小化傾向にあ るが, SJM 弁は弁口面積特性より合理的でありかつ縫 着屯容易であった。したがって高齢者 AVR には複雑な 弁輪桩大法は可及的避けること, MVR では高龄者で 往々異常に脆弱な左室筋への侵襲を加えないこと, 石灰 化AS の沈着石死は十分除去すべきであるが房室伝導障 害防止に留意することなど，慎重な対応が必要である.
術後の NYHA 機能分類での改善度は良好であり，高 齢者弁置換術に際し年齢は制限因子として設けなくても よいと考える.

\section{結 語}

高齿者弁置換術 37 例の手術死亡1例（2.7\%）であっ た. 内科療法で改善が不十分な症例には高龄者弁膜症の 潜在的弱点と対応を十分ふまえた上で，積極的に外科療 法を行ってよいと考える.

文 献 1) Dhingra, R. C. et al.: Ann. Intern. Med. 87: 275, 1977. 2) Rasmussen, K. et al.: Br. Heart J. 52 : 82, 1984. 3) MacMillan, R. M. et al.: Am. Heart J. 110: 56, 1985. 4) Gannon, P. G. et al.: Circulation 33-34(Suppl.): 152, 1966.

\title{
18065 歳以上の弁膜症に対する外科治療成績
}

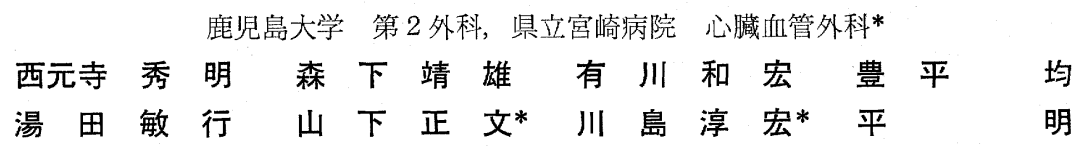

最近の弁膜症手術症例の適忘は高齢者に拡大されつ つある. 教室抒よび関連施設で最近 5 年間に行った弁膜 症手術症例 270 例中 60 歳以上は 65 例 $(23 \%)$ であっ た. 1988 年 1 年間では $29 \%$ に達している. 60 歳以上 のうち, 65 歳以上症例の手術死亡は $26 \%$ と, 65 歳未 満の $5 \%$ に比し高く, 高龄者弁膜症手術の問題点がある と考えた，そこで，65歳以上の症例につき，手術成績 とそれに影響を及活す因子について検討した。

\section{対象および方法}

1984 年 1 月より 1988 年 12 月までの 5 年間で教室拧 よび関連施設で行った弁膜症手術症例 270 例のうち，手

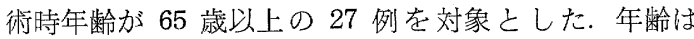
65 72 歳 (平均 68 歳) で, 70 歳以上は 6 例であっ た。男女比は 10 対 17 で，疾患の内訳は僧帽弁膜症 9 例 (MS 4 例, MR 4 例, MSR 1 例), 大動脈弁膜症 9 例 (AS 5 例, AR 1 例, ASR 1 例, $\mathrm{AR}+$ 上行大動脈 瘤 2 例)，連合弁膜症 9 例 ( $A+M \quad 7$ 例， $A+M+T 1$ 例, $\mathrm{M}+\mathrm{T}$ 1例) であった. これらの症例に対して, 12
例に僧帽弁置換術（1 例に三尖弁形成術を同時施行）， 11 例飞大動脈弁置換術 (CABG，僧帽弁形成術，上行 大動脈 wrapping をおのおの 1 例に同時施行)， 3 例に 二弁置換術，Bentall 手術を 1 例に行った．手術は中等 度低体温体外循環下に行い，心筋保護法は cold blood potassium cardioplegia 法を用いた。使用した人工弁は Björk-Shiley 弁 24 個 (M 位 9 個, A 位 15 個), St. Jude Medical 弁 2 個（M位 2 個), Duromedics 弁 2 個 (M位 2 個), Carpentier Edwards 弁 2 個（M位 2 個） であった．術後は全例抗凝固剤として warfarin を投与 し, prothrombin 時間 $30 \%$ を目標にコントロールし た.

術後 30 日以内の手術死亡例を I 群とし, 耐術生存例 をII群とし, 手術成績との関連の因子を $t$ 検定，カイ二 乗検定により検討した。

結果

27 例中手術死亡（I 群）は 7 例であった。死因は心 臟死 5 例，非心臟死 2 例であった，心臓死 5 例の内訳は 
表 1 手術死亡 ( I 群) 之生存 (II群) の比較

\begin{tabular}{|c|c|c|c|}
\hline & I 群 $(n=7)$ & II 群 $(n=20)$ & \\
\hline 男女比 & $5 / 2$ & $5 / 15$ & $p<0.05$ \\
\hline 病悩期間 (年) & $9.7 \pm 4.4$ & $9.0 \pm 8.0$ & N. S. \\
\hline NYHA & $3.1 \pm 0.4$ & $2.9 \pm 0.5$ & N. S. \\
\hline CTR & $59 \pm 11$ & $61 \pm 6$ & N.S. \\
\hline $\mathrm{CI}\left(l / \mathrm{min} / \mathrm{m}^{2}\right)$ & $2.8 \pm 0.8$ & $2.5 \pm 0.6$ & N. S. \\
\hline $\mathrm{EF}(\%)$ & $63 \pm 10$ & $64 \pm 14$ & N. S. \\
\hline 冠動脈狭窄 & $2(29 \%)$ & $1(5 \%)$ & N. S. \\
\hline$\% \vee V(\%)$ & $94 \pm 15$ & $82 \pm 13$ & $p<0.05$ \\
\hline 体外循環時間 (分) & $247 \pm 188$ & $176 \pm 46$ & N. S. \\
\hline 大動脈遮断時間 (分) & $138 \pm 92$ & $109 \pm 32$ & N.S. \\
\hline LOS & $5(71 \%)$ & $9(45 \%)$ & N. S. \\
\hline IABP & $4(57 \%)$ & $5(25 \%)$ & N.S. \\
\hline PMI & $4(57 \%)$ & $3(15 \%)$ & $p<0.05$ \\
\hline 督不全 & $1(14 \%)$ & $1(5 \%)$ & $p<0.05$ \\
\hline
\end{tabular}

Values are mean $\pm \mathrm{SD}$

perioperative myocardial infarction(PMI) 3 例, 左室破 裂，不整脈がおのおの 1 例であった. 非心臟死は $\mathrm{MOF}$, 非閉塞性腸間膜血行不全による腸管壞死 ${ }^{12}$ が各 1 例であ った. PMI は65歳未満の 38 例中にはみられていない。

手術時年齢の 70 歳以上 $(n=6)$ の群は 70 歳未満 $(n=$ 21)の群に比して有意差はないが低死亡率 (17\% VS 29 \%)であった．性別では男性は女性に比較して有意 $(p<$ 0.05) 亿高死亡率 (50\% VS 12\%) を示した. 6 年以上 12 年未満の病悩期間を有する群 $(n=6)$ は 6 年未満の群 $(n=12)$ 亿比較し高死亡率 $(66 \%$ VS $8 \%, p<0.05)$ を示 し，また 12 年以上の群之比較して有意差はないが 高死 亡率 (66\% VS 22\%) を示した. これら 3 群間に心係数, 左室駆出率などには有意の差はなく，長期の病悩期間が 心機能の低下をむたらすとはいえなかった，また疾患 別，術式別でも死亡率に有意の差はみられなかった。

手術死亡 (I 群, $n=7$ ) 之耐術生存 (II 群, $n=20$ ) の 2 群間で手術成績之関連の因子を検討した（表 1 )。両 群間での有意差は男女比, 術後 PMI, 腎不全の発症に みられ，いずれもI群が多かった，病脳期間，NYHA 機能分類, CTR, 心係数, 駆出率, $50 \%$ 以上の主冠動脈 狭窄の合併, 血清ビリルビン值, 血清クレアチニン值, 血清総蛋白, ヘモグロビン值などに雨群間に差はなかっ た. 体外循環時間, 大動脈遮断時間は I 群で延長傾向は みられるものの, 有意差はみられなかった. LOS はI 群の $71 \%$ にみられ, II群に比し多い傾向にあった。

IABP の使用も同様な傾向がみられた。 II 群 20 例の追 跡期間 2 59 か月（平均 23.4 か月）での遠隔期成績 は, 生存 18 例, 遠隔期死亡 2 例（脳血管障害, MOF お の扔の 1 例) であった. 20 例の術後 NYHA 機能分類 は術後 2 か月 $\mathrm{MOF}$ で死亡した 1 例をのぞいてI度 14

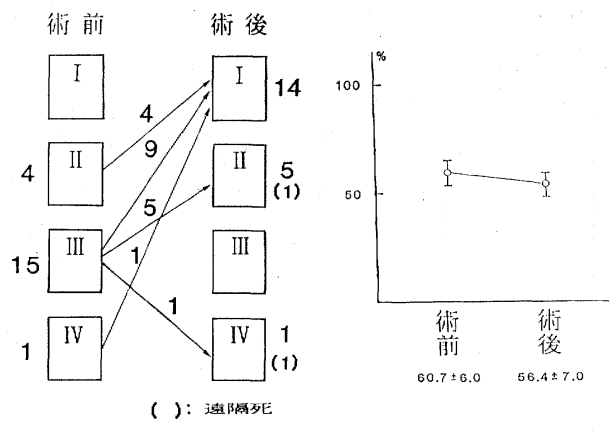

図 1 術前・後での NYHA 機能分類と CTR の推移

例, II 度 5 例で, 著明な改善がみられた。術後の CTR 屯術前の平均 $61 \%$ から $56 \%$ へと減少傾向がみられて いる(図 1). Kaplan-Meier 法による累積生存率も2, $3 ， 4 ， 5$ 年と屯に $88 \%$ を示し，生存 18 例のうち術 後 2 年で追跡不能となった 1 例を除く 17 例は全例, 現 在，元気に社会生活を営んでいる.

\section{考察}

高齢者弁膜症に対する外科治療は，その対象の特殊性 から種々の問題点を指摘されている，高齢による組織の 脆弱性, 長い病悩期間, 冠動脈病変の合併, 他臟器機能 の障害，低栄養状態など2があげられる，今回の手術成 績の檢討から手術死亡の 7 例中 3 例が PMI によるあの であった. PMI は術前冠動脈造影で, 有意の狭窄が存在 する 3 例中 2 例飞発症した. 2 例と屯 CABG を施行せ ず, CABG を行った 1 例には PMI が発生しなかったて とを勘案すると，時間の延長はあるものの，狭窄病変に 対して積極的な CABG を行うことが体外循環時間・大 動脈遮断時間の延長の不利をこえて手術成績の向上につ ながると思われる，ただ，PMI の発症因子として冠動 脈硬化病変のみではないと上も本検討が窅われ，65歳以 上の弁膜症外科治療にあたってはいっそうの心筋保護法 の工夫屯必要と思われる. 術前に冠動脈病変の有無を検 索することはいうまですない，左室破壊の原因の一つと して大きすぎる人弁の装着が考えられる，高齢者の術 後の日常活動を勘案すると, 装着する弁のサイズを考慮 することす一考すべきであろう．また，高齢者の諸臟器 機能の予備力を考えると, 臨床検査上正常範囲内にある と思われるものも細心の注意を払い，術中，術後の管理 を行うことが手術成績の向上汇つながるものと考える.

$$
\text { 結語 }
$$

65 歳以上の㚏膜症手術例 27 例の手術死亡は $26 \%$ 之 
高率でそれ以下の年齢群の $5 \%$ と明瞭に異なる，死亡は 男性に多く, 疾患別, 術式別に差はなかった.70歳以 上は 70 歳未満に比して低死亡率であった. 手術死亡群 では耐術生存群に比し, 術後の PMI, 腎機能障害合併 が多かった，耐術生存例の遠隔期成績はほぼ満足のでき るむので, 暦年齢そのものは高齢者の手術適応決定因子
にはなりえなかった．高齢者の特殊性を十分認識して術 前, 術中, 術後の処理にあたればあっと良好な成績が得 られるものと思われ，積極的な姿勢で臨む考えである.

文 献 1) 森山由紀則ほ加：日胸外会誌 38：1183, 1987. 2) Rahimtoola, S.H. et a1.: J. Am. Coll. Cardiol. 10 (Supple. A) : 60A, 1987. 